\title{
New Periodicals of 1964-Part I
}

\section{BY LUCIA P. JOHNSON and DOROTHY JOENS GLASBY}

Periodicals appearing for the first time in late 1963 or the early months of 1964 exhibit the same seemingly endless variety of subject matter and format evidenced by their predecessors. The collection of titles presented here, it must be remembered, is highly selective. Publications which would appear to be of special interest to libraries and librarians are chosen but many very worthy magazines must be omitted simply because, obviously, there are limits to the time and space which can be devoted to any sort of listing. As in the past, some of the scholarly, scientific, and technical journals whose titles reveal fairly well their contents have not been annotated but are noted in the alphabetical list and are designated there by an asterisk. It has been possible for the first time to cite also the numbers of Library of Congress printed cards for all of the publications included.

AREAs. The interest in other times and other places is always strong and is reflected in the many periodicals devoted to all, or most, aspects of a particular area. Among the new ones to appear is Asia, a publication of the Asia Society (a nonprofit, nonpolitical organization) in New York. Each issue will include five or six papers written by experts in the field and delivered before the society. The articles appear to be authoritative but are written simply enough to be of considerable informational value to a person with only a limited knowledge of the subject. The first issue includes "Population: Dilemma of Modernization in Southeast Asia," "The Nature of Philippine Economic Nationalism," and "Western Culture and the Thai Way of Life."

From the British Institute of Persian Studies comes their new journal, Iran. It is a handsome, well illustrated publication and includes primarily scholarly material on Persian literature, culture, and archaeology.
Miss Johnson has been, and Mrs. Glasby is now, a Serials Cataloger in the Descriptive Cataloging Division of the Library of Congress.

Libraries with extensive East European collections may be interested in Bulgaria, a propaganda-type magazine published in Sofia and superseding Bulgaria Today and New Bulgaria.

Probably no discussion of new periodicals would be complete without mentioning at least one concerned with Africa. Situations in Africa have changed so rapidly in the past few years and interest has been so aroused in things African that even so modest a publication as Bulletin of African Studies in Canada, issued by the Committee on African Studies in Canada, should find a ready audience. Intended primarily for Africanist scholars and institutions in Canada, and with a text in English and French, its purpose is to disseminate information on progress in research, conferences, and other developments of note.

ART. Devoted to photography, Terre d'Images thoroughly covers that subject in at least two aspects: as science and as art. It includes a section on techniques, technical material in regard to equipment, information on the history of photography, and current events material such as club meeting announcements and lists of publications available. The magazine, as one might expect, is profusely illustrated and its first issue gives many pages to photographic essays, groups of pictures on one theme, or single pictures expressing the emotions of either the photographer or the subject.

Another heavily illustrated publication, Anno Domini; the Magazine of Religious Arts and Crafts Today, intends to be "international, theologically oriented, and completely ecumenical" (laudable ambitions, certainly, but somewhat hard to follow completely, one would imagine). Vol. 1, no. 1 
has articles and criticism on Christian painting, sculpture, and architecture as well as sections devoted to theater, films, and new books. It includes also, in a section devoted to crafts, the first of a three-part article giving step-by-step directions on "Elementary Enameling."

BIBLIOGRAPHY, Libraries. Heading the list of publications of special interest to librarians is, of course, ACRL's Choice; Books for College Libraries. Its appearance, March 1964, marks the culmination of five years of planning by ALA. Designed to meet the book-reviewing needs of college libraries more specifically than either the popular media or the long delayed scholarly reviews, Choice is especially aimed at the 60 per cent of all college and university libraries that have less than $\$ 20,000$ a year to spend on books and related materials. Since it was designed to fill a known gap, one can expect that the publication will have a long, and judging from the first issue, useful life.

Another possible book selection aid for librarians is Books, a newssheet of events and information in the publishing world aimed, probably, at the book trade. Its first issue announces a posthumous edition of A. J. Liebling's "The Press," discusses three planned biographies of President Johnson, and includes a large number of pictures from dust jackets and portraits of authors.

As the serif adds weight to a letter to make it truly visible so Kent State University library's The Serif aims to add emphasis to "make books more meaningful and bookish scholarship a matter of more purpose." The publication will concern itself with things that are of library interest and plans articles on the history of printing, history of publishing, field of book arts, and field of literary and historical bibliography. Examples, illustrations, and much information will be drawn from the collections of Kent State University library and each issue will include, also, an illustration of a book plate from among the thirty-five thousand in the library's M. E. Thurston bookplate collection.

A bibliography, Atlantic Studies, Etudes Atlantiques, will list current and proposed studies concerning economic, political, and military problems of the Atlantic countries and problems arising from their relations with other countries. As each item achieves publication it will be removed from the list.

BUSINESS AND ECONOMICS. In the area of management, two new publications seem worthy of note. From Britain, The Journal of Management Studies puts its emphasis on the systematic investigation of management and will include articles on organization structure, management selection and development, decision-making, and similar matters. An American publication, Management Services, is somewhat more specialized and, in quite a technical way, studies electronic data processing and its applications and implications for integrated management of office operations from the point of view of the CPA.

Industrial and Labor Relations Forum, issued from New York State school of industrial and labor relations at Cornell University, claims to be the first magazine on industrial and labor relations published entirely by students. The first issue is mimeographed and contains only four articles but future plans are to include term papers and articles of original research judged by the editors to be especially worthy and the publication hopes to encourage more independent thinking (all too rare today) and create a willingness to support a controversial view.

Latin America is the concern of Desarrollo Económico, a publication intended for "professionals" in the field of development, and supplied without cost to anyone who fits the magazine's definition of such a worker. A few subscriptions are available to outsiders, however, and the first issue would lead one to believe that it and future issues would be of considerable value and interest to both professional and layman. Articles report actual experiences as well as some plans for the future and will cover development in many fields such as agriculture, industry, construction, health, and education.

Education. The American Educational Research Association, a department of the National Education Association, plans to publish "original reports of experimental and theoretical studies in education" in its American Educational Research Journal. A rather specialized approach to education is reflected in Psychology in the Schools which 
will include articles on subjects ranging from the role of the psychologist in the school to research on teacher education and the psychology of various types of instruction.

General. The field of the general magazine is marked by the return of two familiar names, although the term "revival" cannot be used with similar weight in both cases. The editorial staff and the publisher are different, but Coronet has assumed the name and taken on the format of a popular predecessor of that name which began in 1936 and died in October 1961.

The March 1964 issue of The North American Review is designated as New Series, Vol. 1, no. 1 so leaves no doubt that it is, indeed, to be regarded as a rebirth of the magazine considered one of the foremost journals of public opinion during much of its 125 years of existence. The earlier publication came to an ignominious end in 1940 when it was discovered that its new owner was an agent of the Japanese government. In a format much like that of Harper's Magazine, the new journal is published with the cooperation of Senator Claiborn Pell of Rhode Island, and its first issue augurs well for the future as it includes articles by Robert Penn Warren, Frank Luther Mott, Salvador de Madariaga, and Sir Julian Huxley.

As something of a counterpart to Jet and Ebony, the new Bronze America will include articles on integration in Los Angeles, career opportunities, and religion, and will feature prominent Negroes in the fields of sports and religion.

History. Probably one can never feel that he has heard enough about "how it was" in the early days of the western United States so the magazine of the Western History Association, The American West, can surely find readers and users even though it concerns an era about which so much has been written. Vaguely reminiscent of American Heritage, the new publication's first issue is lavishly illustrated and contains information concerning Fremont's adventures in Arizona, the history and folklore of the West, and historians of the West.

InTERnational Affairs. With the beginning of Disarmament the World Veterans Federation initiates a new service the purpose of which is "to provide authoritative, objective, and easily understandable information about current negotiations for disarmament and reduction of the risks of war." The first issue includes: "The Moscow Treaty on the Cessation of Nuclear Tests" and "The Status of the Negotiations on General and Complete Disarmament." Included in that issue, also, are texts of recent disarmament agreements (the Test Ban Treaty and the No Bombs in Orbit resolution of the United Nations General Assembly, for example). Promised for future issues are articles concerning France's abstention from the Geneva deliberations, consequences to the world economy of disarmament, and ways and means of preventing the spread of nuclear weapons.

The United Nations' latest periodical, $U N$ Monthly Chronicle, is available also in French and Spanish editions and supersedes the earlier United Nations Review. It will report, in what would appear to be somewhat greater detail than did the $R e$ view, on activities of the UN and related agencies. In addition to summaries of statutes, speeches, and business transacted during the month, the Chronicle will incorporate more lengthy articles concerning long range plans or trends. U Thant, UN secretary-general, in his introduction to the first issue, perhaps best expresses what is planned for the publication when he writes that it is a "record of what the United $\mathrm{Na}$ tions thinks and says and does, written for the world by the world organization itself."

LANGUAGE AND LITERATURE. The Journal of West African Languages, a rather specialized publication, is being issued by Cambridge University Press in association with the Institute of African Studies of the University of Ibadan (until December 1962, Ibadan University College). The editors are interested in word lists, notes on dialectal variations, and, in fact, almost any material concerning these languages of which previously little or nothing (in some cases, not even the existence) was known. It is hoped that the dissemination of such material to linguists everywhere will act as a stimulus and starting point for further investigations of this relatively untouched field of study. The first issue contains "A Word-List of Eloyi" and "The Syntax of Emphasis in Kpella."

One of the new little magazines, The 
Smith, has essays, stories, and poetry as well as some rather modern illustrations. The authors represented in its first issue do not appear to have published extensively elsewhere. Art and Literature, on the other hand, is a somewhat more substantial production and its contributors seem to be internationally well known. In addition to poetry and fiction, the publication will include art and literary criticism.

Satire Newsletter, as its name implies, will concern itself with satire, past and present. The publication plans critical articles as well as original satire. While the first issue is concerned with the past and includes articles on Gulliver and on the Roman satirists, a discussion of such contemporary satire as "Beyond the Fringe" and "The Premise" has been promised for the second.

The quarterly, Studies in Short Fiction, is a collection of critical articles from editors of anthologies and teachers of English from all over the country.

Law. The Harvard Student Legislative Research Bureau is an organization whose student members, under faculty supervision, draft legislation at the request of lawmakers throughout the country. The bureau's Harvard Journal on Legislation will present some of these model drafts, in addition to articles by prominent lawyers and politicians, in the hope that in the future a collection of such drafts of legislation will be built up which will constitute a guide to legislative precedents and thought in any area.

Law in Transition Quarterly, a publication of the Institute of Modern Legal Thought, devotes itself to the interrelationship between law and the social sciences. Articles will be concerned with some of the controversial problems involving the rights and liberties of the individual and of the states as evidenced by the first issue which discusses "Federal Habeas Corpus for State Prisoners" and "Expatriation and the Constitution."

Medicine. Each year seems to mark the birth of many new journals in the field of medicine. Some of them, of course, are very specialized and deal with a relatively small subject in great depth while others cut across all subject lines in an attempt to spread information that will be of value to more than one discipline. Among some of the latest to appear is Birth Defects; $A b$ stracts of Selected Articles which is a publication of the National Foundation. The journal will provide abstracts of articles from over twenty six hundred publications in seventeen languages. Vascular Diseases, official journal of the American College of Angiology and the International College of Angiology, presents highly technical articles in its special field.

Monographs in the Surgical Sciences, intended as a counterpart to the same publisher's Medicine (issued since 1922), will provide an opportunity for an author to present his work in greater depth than would be the case in the standard surgical journals. Each issue will include two or three monographs averaging about forty pages which treat all aspects of a subject with particular emphasis on the author's experimental and clinical observations. The monographs in the first issue are extensively illustrated and include lengthy bibliographies.

Each issue of Modern Treatment will contain one or two symposia concerned with current practices in treatment in certain critical areas. The first issue, for example, discusses renal disease and thyroid disease while later issues are planned to include anemias, epilepsy, and liver disease. Each issue will contain an index which cumulates the indexes of all previous issues (how long can they keep this up?).

Issued as Excerpta Medica, section 23, Nuclear Medicine will abstract world literature in its field. Abstracts, unsigned, will be prepared by the author or Excerpta Medica Foundation's editorial staff and each issue will include author and subject indexes with annual cumulations for each volume. The publication is issued in cooperation with the European Atomic Energy Community (EURATOM).

The Institute for the Study of the USSR, Munich, is issuing Review of Soviet Medical Sciences to supersede Review of Eastern Medical Sciences which was published from 1956 to 1958 as a private undertaking of its editor, Dr. H. Schulz, but had to be abandoned with issue no. 12 because of financial and technical difficulties. The new publication contains scholarly, well documented articles on all aspects of the theory and 
practice of medicine in the USSR and will include sections on past and future medical meetings as well as a chronicle of events. Because five years have passed since the earlier work ceased publication, the first issue contains a chronicle of the most important events in the medical life of the USSR which have occurred in the time from the beginning of 1959 to June 1963 . Although the USSR is the main concern of the editors, current developments in other countries will be mentioned from time to time "since the main features of the Soviet health services have been adopted by various countries in Eastern Europe and the Far East."

Music. Published in a newspaper format with some pictures, Listen is a comprehensive review of criticism with factual accounts of all kinds of music from grand opera and chamber music to jazz and folk song.

PhILosophy. Through The Philosophical Journal the Royal Philosophical Society of Glasgow has resumed publication of its Proceedings (vols. 1-76; 1841/44-1951/52) in the hope of reaching a wider audience. The journal will publish not only papers given before the society but also outside contributions on topics within the society's general aims.

RECREATIONS. Moviegoer is a magazine of criticism which reviews old and current art films. The authors of many of the articles in its first issue have published in other established journals.

Published as "a monthly supplement to all Whitman standard coin reference books," Whitman Numismatic Journal is being issued primarily to keep up to date $A$ Guide Book of U.S. Coins and A Catalog of Modern World Coins. The monthly will also include articles on all phases of numismatics and incorporates, of course, many illustrations. The monthly Vogel-Kosmos is probably intended for the amateur birdwatcher or ornithologist. The magazine will include everything about birds (raising them, observing them, breeding them, studying them). Articles in the first issue are personal experiences or field observations presented in rather a narrative way and are not at all the documented, scientific type.
There are many attractive black-and-white illustrations.

Religion. Because of the fact that much of the instruction in a Catholic educational institution consists of informing the student in consequence of the Church's commitment to certain doctrines, the editors of Stimulus feel that the student may not develop the questioning, critical attitudes necessary for true maturity. The periodical, published by the students of the Catholic colleges in the Washington, D.C. area (Trinity, Dunbarton, Georgetown, and Catholic University) hopes to raise vital questions and promote discussion and controversy. The first issue treats of the Church and birth control, civil rights, and the professional college athlete.

Journal of Ecumenical Studies is edited by a board which includes Catholic, Protestant, and Orthodox theologians and churchmen. The journal will discuss the problems of scripture versus tradition, liturgy, and the ministry as well as questions on historical, Biblical, and theological matters.

SCIENCE. As the title implies, Education in Chemistry devotes itself to methods and theories of instruction for teachers of all levels. The first issue contains in addition to articles, notices of courses and symposia, and reviews of recent books and films. Surface Science is a scholarly technical journal "devoted to the physics and chemistry of interfaces." Electroanalytical Abstracts, published in Basel, supersedes the Abstracts section of the Journal of Electroanalytical Chemistry and will abstract about five hundred periodicals or approximately two thousand papers yearly.

Journal of Aircraft and Journal of Spacecraft and Rockets are companion publications issued by the American Institute of Aeronautics and Astronautics. The first is composed of technical articles on the advancement of the science and technology of airborne flight while the second is concerned with applied engineering in the field of space flight.

The Institute of Electrical and Electronics Engineers is issuing, as their primary journal, the IEEE Spectrum. The publication will contain "review and tutorial articles, and occasionally articles of broad and fundamental import." In addition, of course, 
the journal will be a disseminating agency for news of the profession as well as of the IEEE.

Russian Physics Quarterly is one of the latest of many periodicals devoted to the attempt to keep American scientists informed concerning discoveries and work in the Soviet Union. Each year the new quarterly will publish approximately sixty of the best of the Russian articles on original research in physics. Of perhaps limited interest to Americans, Science Reporter is intended to popularize science among educated Indian laymen so as to provide more communication between the creators of new techniques and the people who will utilize these techniques in solving the material problems of the country. Published in New Delhi, the periodical includes popular articles on a variety of subjects from techniques for mapping cholera to results of recent investigations of the sun.

Social ScIEnce. Contemporary democratic socialism, the Yiddish heritage, and the problems of the Jewish people as a cultural-national minority are the areas of interest of Perspectives published in New York by the Jewish Labor Bund. Vie Sociale, superseding the Cahiers of the Musée Social, concerns itself with social work and current social legislation as well as information on the work of its publisher, the Centre d'études, de documentation, d'information et d'action sociales in Paris.

Jointly sponsored and published by the National Council on Crime and Delinquency and the Center for Youth and Community Studies of Howard University, The Journal of Research in Crime and Delinquency publishes research articles from con- tributors without regard for national boundary. The journal is not for the layman. The first issue has scholarly articles on "SocioEconomic Status and Delinquency Behavior: a Retest" and "Types and Patterns of Delinquency in a Middle-Sized City."

In an attempt to give as comprehensive a view as possible of "one of the most telling social problems of our time" the Missionaries of Saint Charles, Province of Saint Charles, Staten Island, N.Y., are publishing The International Migration Digest. Its purpose is to "encourage further advancement in the study of social and geographic mobility by presenting a multilateral coverage of activities and research in this field." Each issue will have five departments: articles, legislation, news, statistics, and books.

Technology. Primarily for "energy executives" all over the world, Energy International describes some of the vast new projects (such as hydro-electric projects and Italy's new power authority) in progress or completed.

Building Research includes articles devoted to the exploration of new ideas and concepts not only in architecture but in the whole field of modern living as it is influenced by the types of dwellings in which America lives today. Although some of the articles are quite technical, judging from the first issue, it would seem that at least some of them will be of interest even to those with no special knowledge of the field.

Published by the International Institute of Welding in London, Welding in the World includes technical articles with text in both English and French.

\section{Periodicals}

American Educational Research Journal. American Educational Research Association, 1201 16th St., N.W., Washington, D.C. 20036 . v. 1 , no. 1 , Jan. 1964. 4 no. a year. \$6. 64-9394.

The American West. Lane Book Company, Willow Road, Menlo Park, Calif. v. 1, no. 1, Winter 1964. Quarterly. \$6. 64-9374. Anno Domini; the Magazine of Religious Arts and Crafts Today. Religious Pub- lishing Company, 122 Old York Road, Jenkintown, Pa. 19046. v. 1, no. 1, May/ June 1964. Bimonthly. \$4. 64-9405.

Art and Literature. Eastern News Distributors, Inc., 255 Seventh Ave., New York 1. no. 1, Mar. 1964. Quarterly. \$7. 64-9401. Asia. The Asia Society, Inc., 112 East 64th St., New York 10021. no. 1, Spring 1964. Frequency not given. \$1 per copy. 649388. 
Atlantic Studies. Etudes Atlantiques. Atlantic Institute, 24 Quai du 4-Septembre, Boulogne-sur-Seine, France. v. 1, no. 1, 1964. Frequency not given. Price not given. 64-9403.

Birth Defects; Abstracts of Selected Articles. National Foundation, Supply Division, Room 555, 800 Second Ave., New York 10017. v. 1, no. 1; Jan. 1964. Monthly. $\$ 5.64-9385$.

Books. 598 Madison Ave., New York 10022. v. 1, no. 1, Feb. 1964. Monthly. \$3. 64-9370.

Bronze America. Colorful Publications Inc., 2400 South Western Ave., Los Angeles. v. 1 , no. $1,1963.6$ no. a year. Price not given. 64-9356.

Building Research. Building Research Institute, Inc., 1725 De Sales St. N.W., Washington, D.C. 20036. v. 1, no. 1, Jan./Feb. 1964. Bimonthly. \$35. 64-9377.

Bulgaria. Dolphin Service, P.O. Box 8927, Washington 3, D.C. v. 1, no. 1, Jan. 1964. Monthly. \$3. 64-9400.

Bulletin of African Studies in Canada. Committee on African Studies in Canada, Donald L. Wiedner, c/o Dept. of History, University of Alberta, Edmonton. v. 1, no. 1, Nov. 1963. Semiannual. Free. 649378.

*CORS Journal. Subscription Manager, Canadian Operational Research Society, P.O. Box 2225, Station D, Ottawa, Ontario. v. 1 , no. 1 , Dec. 1963 . Frequency not given. \$5. 64-9352.

CHOICE: Books for College Libraries. Subscription Dept., American Library Association, 50 E. Huron St., Chicago 60611. v. 1 , no. 1 , Mar. 1964. Monthly. \$20. 64-9413.

*The Cleft Palate Journal. American Cleft Palate Association, c/o Charlotte G. Wells, PhD, 106 Parker Hall, University of Missouri, Columbia 65202. v. 1, Jan. 1964. Quarterly. \$4. 64-9397.

Coronet. H. S. Publications, Inc., 260 Park Ave. South, New York 10010. v. 1, no. 1, Dec. 1963. Monthly. \$4. 64-9422.

Desarrollo Económico. 25 W. 45th St., New York 10036. v. 1, no. 1, May/June 1964. Frequency not given. \$12. 64-9416.

Disarmament. World Veterans Federation, 16 rue Hamelin, Paris (16). no. 1, 1964. 4 no. a year. \$1.50. 64-9406.
Education in Chemistry. Royal Institute of Chemistry, 30 Russell Square, London WC 1. v. 1, no. 1, Jan. 1964. Frequency not given. \$7. 64-9381.

Electroanalytical Abstracts. Birkhäuser Verlag, Basel, Switzerland. v. 1, no. 1, Aug. 1963. Monthly. 150 Swiss francs. 649380.

Energy International. Energy Publications, Inc., 500 Howard St., San Francisco 94105. v. 1, no. 1, Mar. 1964. Monthly. \$5. 64-9402.

Harvard Journal on Legislation. Harvard Student Legislative Research Bureau, Langdell Hall, Harvard Law School, Cambridge, Mass. v. 1, no. 1, Jan. 1964. Semiannual. \$2. 64-9360.

*Health Laboratory Science. American Public Health Association, 1790 Broadway, New York 19. v. 1, no. 1, Jan. 1964. Quarterly. \$6. 64-6369.

IEEE Spectrum. Institute of Electrical and Electronics Engineers, Inc., Box A, Lenox Hill Station, New York 10021. v. 1, no. 1, Jan. 1964. Monthly. \$13.50. 64-9423.

*IEEE Transactions on Geoscience Electronics. Institute of Electrical and Electronics Engineers, Inc., Box A, Lenox Hill Station, New York 10021. v. GE 1, Dec. 1963. Frequency not given. \$17. 64-9350.

Industrial and Labor Relations Forum. 125 Ives Hall, New York State School of Industrial and Labor Relations, Cornell University, Ithaca 14850 . v. 1 , no. 1 , Mar. 1964. Quarterly. \$5. 64-9376.

*International Journal of Rock Mechanics and Mining Sciences. Pergamon Press, Inc., 122 East 55th St., New York 22. v. 1, no. 1, Jan. 1964. Quarterly. \$30. 649408.

The International Migration Digest. Saint Charles Seminary, 209 Flagg Place, Staten Island, N.Y. 10304. v. 1, no. 1, Spring 1964. Semiannual. $\$ 3.25$. 64-9426.

Iran. British Institute of Persian Studies, c/o British Academy, Burlington Gardens, London, W 1. v. 1, 1963. Annual. £2. 10s. 64-9404.

Journal of Aircraft. American Institute of Aeronautics and Astronautics, 20th and Northampton Sts., Easton, Pa. v. 1, no. 1, Jan./Feb. 1964. Bimonthly. \$10. 649368. 
Journal of Ecumenical Studies. Duquesne University Press, Pittsburgh, Pa. 15219. v. 1 , no. 1 , Winter 1964 . 3 no. a year. \$6. 64-9393.

*Journal of Experimental Child Psychology. Academic Press, Inc., 111 Fifth Ave., New York 10003. v. 1, no. 1, Apr. 1964. 4 no. a year. \$15. 64-9409.

*Journal of Heterocyclic Chemistry. Box 8666, Albuquerque, N.M. 87108. v. 1, no. 1, Feb. 1964. Frequency not given. \$20. 64-9375.

The Journal of Management Studies. Basil Blackwell, Broad Street, Oxford, England. v. 1 , no. 1 , Mar. 1964. Semiannual. $£ 1$. 64-9431.

The Journal of Research in Crime and Delinquency. Rudolph Moz, Executive Editor, National Council on Crime and Delinquency, 44 East 23d St., New York 10010. v. 1, no. 1, Jan. 1964. Semiannual. \$4.50. 64-9395.

*Journal of Sound and Vibration. Academic Press, Inc., 111 Fifth Ave., New York 10003. v. 1, no. 1, Jan. 1964. Quarterly. \$18. 64-9418.

Journal of Spacecraft and Rockets. American Institute of Aeronautics and Astronautics, Inc., 20th and Northampton Sts., Easton, Pa. v. 1, no. 1, Jan./Feb. 1964. Bimonthly. \$15. 64-9399.

The Journal of West African Languages. Cambridge University Press, American Branch, 32 East 57th St., New York 22. v. 1 , no. 1, Jan. 1964. Semiannual. \$5.50. 64-9419.

Law in Transition Quarterly. Institute of Modern Legal Thought, Inc., P.O. Box 3332, Beverly Hills, Calif. 90212. v. 1, no. 1, Winter 1964. Quarterly. \$5. 649383.

Listen. AGR Publishing Corp., 1265 Broadway, New York 1. v. 1, no. 1, Dec. 1963. 10 no. a year. $\$ 3.64-9433 / \mathrm{MN}$.

Management Services. 666 Fifth Ave., New York 10019. v. 1, no. 1, Mar./Apr. 1964. Bimonthly. \$7.50. 64-9387.

Modern Treatment. Hoeber Medical Division, 49 East 33d St., New York 10016. v. 1 , no. 1 , Jan. 1964. Bimonthly. \$16. 64-9392.

Monographs in the Surgical Sciences. Williams \& Wilkins Co., 428 East Preston St., Baltimore 21202. v. 1, no. 1, Mar. 1964. Quarterly. \$10. 64-9417.
Moviegoer. Box 128, Stuyvesant Station, New York 9. no. 1, Winter 1964. Quarterly. $\$ 1$ per issue. 64-9354.

The North American Review. Cornell College, Mount Vernon, Iowa. New series, v. 1, no. 1, Mar. 1964. Quarterly. \$3. 4-12673.

Nuclear Medicine. Excerpta Medica Foundation, New York Academy of Medicine Building, 2 East 103d St., New York 29. v. 1, no. 1, Jan. 1964. Monthly. \$30. 649390.

Perspectives. 25 East 78th Street, New York 10021. v. 1 , no. 1 , Winter 1964 . Quarterly. \$1.50. 64-9429.

The Philosophical Journal. Oliver \& Boyd, Ltd., Tweeddale Court, 14 High St., Edinburgh 1, Scotland. v. 1, no. 1, Jan. 1964. Semiannual. \$3.50. 64-9414.

Psychology in the Schools. Psychology Press, Brandon, Vt. v. 1, no. 1, Jan. 1964. Quarterly. \$10. 64-9353.

*Pyrodynamics. Gordon and Breach Science Publishers, Inc., 150 Fifth Ave., New York 10011. v. 1, no. 1/2, Jan./Feb. 1964. Frequency not given. \$25. 64-9424.

${ }^{*}$ RES; Journal of the Reticuloendothelial Society. Academic Press, Inc., 111 5th Ave., New York 10003. v. 1, no. 1, Jan. 1964. 6 no. a year. \$16. 64-9396.

Review of Soviet Medical Sciences. Institute for the Study of the USSR, Munich, Mannhardstrasse 6, Germany. v. 1, no. 1, 1964. Quarterly. \$6. 64-9420.

Russian Physics Quarterly. International Physical Index, Inc., 1909 Park Ave., New York 35. v. 1, no. 1, Fall 1963. Quarterly. \$100. 64-9359.

Satire Newsletter. State University College, Oneonta, N.Y. v. 1, no. 1, Fall 1963. Semiannual. \$2. 64-9355.

Science Reporter. Sales \& Distribution Officer, Council of Scientific \& Industrial Research, Rafi Marg, New Delhi-1, India. v. 1 , no. 1 , Jan. 1964 . Monthly. Rs. 5. 64-9386.

The Serif. Kent State University Library, Kent, Ohio. v. 1, no. 1, Apr. 1964. Quarterly. \$3. 64-9427.

The Smith. The Smith, Ltd., 15 Park Row, New York 10038. v. 1, no. 1, Feb. 15, 1964. Frequency not given. Price not given. 64-9367.

Stimulus. S. R. Bell, 25 North Bedford St., Arlington, Va. v. 1, no. 1, Apr. 1964. 
Frequency not given. $\$ .35$ per issue. 649389.

Studies in Short Fiction. Newberry College, Newberry, S.C. v. 1, no. 1, Fall 1963. Quarterly. \$4. 64-9357.

Surface Science. North Holland Publishing Company, P.O. Box 103, Amsterdam. v. 1 , no. 1 , Jan. 1964. Quarterly. \$16. 649351.

Terre d'Images. Michel Brient et Cie, 64 rue de Saintonge, Paris 3, France. no. 1, Jan./Feb. 1964. Bimonthly. 50 n.f. 649415.

UN Monthly Chronicle. Sales Section, Publishing Service, United Nations, New York. v. 1, no. 1, May 1964. Monthly. \$6. 64-9411.

Vascular Diseases. The Angiology Research
Foundation, Inc., 32 Broadway, New York 10004. v. 1, no. 1, Jan. 1964. Bimonthly. \$10. 64-9372.

Vie Sociale. Centre d'études, de documentation, d'information et d'action sociales, 5 Rue las-Cases, Paris (VII). no. 1, Jan. 1964. Monthly. 38.50 n.f. 64-9398.

Vogel-Kosmos. Franckh'sche Verlagshandlung, Pfizerstrasse 5-7, 7000 Stuttgart 1, Germany. Heft 1, Jan. 1964. Monthly. 5.70 DM per quarter. 64-9428.

Welding in the World. International Institute of Welding, 54 Princes Gate, Exhibition Road, London SW 7. v. 1, no. 1, 1963. Quarterly. £3. 15s. 64-9382.

Whitman Numismatic Journal. 1220 Mound Ave., Racine, Wis. v. 1, no. 1, Jan. 1964. Monthly. \$3.50. 64-9371.

\title{
Recruiting - New, and Still Interesting
}

\begin{abstract}
ALA's Office for Recruitment now has reprints of an Esquire magazine page (April 1964) devoted to librarianship as a career for young men, and those not so young, with emphasis on academic and research librarianship. Single copies are free; 25 copies, $\$ 1 ; 50$ copies, $\$ 1.75 ; 100$ copies, $\$ 2.50$; more than $100,2 \varnothing$ each.

The Office for Recruitment also has available booklets in the Demco Series: No. 1, The Librarian-Idea Consultant; No. 2, Future Unlimited: What You Need to be a Librarian; No. 3, The Exciting Career of a School Librarian. Single copies are free; 25 copies, $\$ 1.25 ; 50$ copies, $\$ 2.25 ; 100$ copies, $\$ 4 ; 250$ copies, $\$ 9.25 ; 500, \$ 15 ; 1000, \$ 28$.

The Hospital Librarian is also available free for a single copy, and in bulk orders for the same prices as the Demco booklets. Fellowships, Scholarships, Grants-in-Aid, Loan Funds and Other Financial Assistance for Library Education (Library Education Division of ALA is the publisher) is an extensive list which should be useful to both recruiter and potential recruit. So also should be Scholarships, Fellowships, Loans, Grants-in-Aid for School Librarianship. Single copies of the first (LED) list are $50 \notin ; 10$ copies, $\$ 4.50 ; 25$ copies, $\$ 11 ; 100$ copies, \$40. The list of financial assistance for school librarianship is $\$ 1$ for a single copy; 10 copies, $\$ 9 ; 25$ copies, $\$ 20 ; 100$ copies, $\$ 75$. All items are available from the Office for Recruitment, ALA, 50 E. Huron St., Chicago 60611.
\end{abstract}

